\title{
The formal method in Germany and Russia: the beginnings of European psycholinguistics
}

Research Article

\author{
Serge Tchougounnikov* \\ University of Burgundy, Department of Arts, Dijon, France
}

Received 30 November, 2018; Accepted 6 December, 2018

Abstract: German-Austrian psychology is a direct source of the European formalism movement both in the German context (Germany, Austria) as well as in Russia. This interest of the formalists in the corporeal component of linguistic and literary production has resulted in a particular research stream, which could be defined as a 'linguo-somatic orientation'. In particular, this is the case of Alois Riegl's [1] perceptive 'tactile-optical' method; Adolf von Hildebrand's [2] architectonic conception; Konrad Fiedler's [3] 'sensorial aesthetics' ; W. Wölfflin's [4] 'basic concepts' of the art history, W. Worringer's [5] psychological arts typology as well as Oskar Walzel's soundcorporeal poetics elaborated during 1920 [6]. Within Russian formalism, psychological notions (such as 'representation', 'sensation', 'apperception', 'series', 'clear and dark zones of consciousness', 'verbal gestures' and 'sound gestures') are fundamental in nearly all the formalist conceptions (Viktor Šklovskij, Evgenij Polivanov, Lev Jakubinskij, Osip Brik, Boris Eixenbaum and Jurij Tynianov). This psychological background constitutes a rather heterogeneous constellation composed of psychological aesthetics and psychological linguistics of the second half of the 19th century. Independently of its intrinsic theoretical values, the formalist way of thinking about language and literature is based on the implicit dominance of psychology, which takes its sense only with respect to the German cognitive tradition, appropriated by the Geisteswissenschaften of this time. In this respect, European formalism participates in the large movement of psychologisation of the humanities. To this extent, the case of Russian formalism is really representative: it invites the rethinking of the genealogy of European structuralism in general. This accumulation of conceptual tools borrowed from the German psychological tradition also reveals a cognitive charge of the formalist theories. The latter constitute a conceptual link between the properly psychological past of the European Geisteswissenschaften and the 'cognitive' future of the actual research programmes. Beyond the borrowing of conceptual tools from the psychological trend, the formal method has found in psychology its inspiration for producing new models of analysis. This intrinsically cognitivist dimension of the formalist programme explains its late success during the 1950s-1960s, the period often and abusively called the period of the cognitivist revolution. In reality, it deals with the re-emergence of the research programme of the cognitivist sciences, rather exhaustively formulated by the German psychological tradition..

Keywords: formalism • psychological linguistics • German-Austrian psychology • psychologisation

\section{The starting point: the psychological substratum of Russian formalism}

The starting point of this research was the following fact. Since the beginning of my work with the texts of the Russian Formalist Circle, I have encountered some formalist concepts that seemed rather obscure for me: appercepcija (apperception); rjady (series); temnoe $i$ svetloe pol'e soznanija (clear and dark fields of the consciousness); jazykovoj žest (lingual gestures); and 'zvukovoj žest' (sound gesture). I could guess that these opaque concepts were seemingly referring to some psychological matters. At any rate, the impression I had was that these concepts were building some system of references that I was unable to follow.

I will give some examples of these opaque concepts, for instance, the notion of apperception, which I found in the texts of such formalists as Yuri Tynianov and Evgenii Polivanov. For example, Tynianov uses this term in his article 'The literary fact' [7]. This notion is somewhat more elaborated by Polivanov in his articles of the 1930s, collected in his book Za marksistsoje jazykoznanije (Towards the Marxist Linguistics). Thus, Polivanov uses the terms appercepcija (apperception) and appercepcionnaja dejatel'nost' (apperceptive activity) in his article 'Gde ležat pričiny jazykovoj evolucii ?' [What are the reasons of the linguistics evolution?] [8]. Polivanov applies this term in relation to the principle of the economy of psychic energy. For Polivanov, the economy of psychic energy is

\footnotetext{
*Corresponding author: Serge Tchougounnikov, E-mail: serge.tchougounnikov@yahoo.fr 
the fundamental principle of the functioning of language. This principle is based on the mechanism of the psyche; it is perceived by Polivanov as the most important factor in the evolution of the psychic organism ([8, pp. 43-47]; see also other contexts of this concept in papers by Polivanov: [9, pp. 60, 236]; [10 , p. 67]).

Later, I found the same term in texts by Valentin Vološinov, who is not a formalist but who is traditionally considered as a member of Mikhail Baxtin's circle: Vološinov speaks about the 'apperceptive background on which one perceives lingual phenomena' [11, pp. 369-371].

The next example is of the frequently used formalist terms rjad and rjady, which mean 'series' or 'row'. They often refer to literary or poetical series and, sometimes, also to economical series and everyday life series. One should remember that from the very beginning of the formalist movement, its programme sought to isolate pure literary or poetical series.

Thus, in writings by Tynianov, this term is very frequent. In his famous article 'On the literary evolution', Tynianov [12] defines his research programme as the study of homogeneous phenomena or series. He bases his idea of literature as a system on this notion. According to him, a systematic correlation between a literary work and literature in general can allow for a scientific study of homogeneous phenomena and series 'in place of the chaos of heterogeneous phenomena and series'. In this context, Tynianov [12, p. 436] speaks about the role of 'neighbouring series' (sosednijerjady) in literary evolution. Tynianov's summary of this point is as follows: 'the study of the literary evolution is only possible if one considers his research object as a series, a system correlated with other systems or series of systems conditioned through these series' (ibid., pp. 458-459).

And then, late formalism speaks about the necessity to study the correlation and convergence of series (in the 'Theses about the study of language and literature', signed by Jakobson and Tynianov in 1928) [13].

One understands the global sense of these argumentations, but the very nature of these 'pure literary or poetical' series and neighbouring series seems to be far from being clear (to me, at least). Particularly, this way of dividing phenomena into series seems to look rather strange.

Yet another example of these opaque concepts is the notion of 'clear and dark fields of the consciousness'. Thus, Lev Jakubinskij uses it in his study of the sounds of poetical language of 1916 : Jakubinskij [14, p. 163] further writes as follows: 'In the discursive expression of the practical thought, the attention of the speaker is not concentrated upon the sounds; the sounds can not attain the clear field of the consciousness (svetloje pole soznanija) and they do not possess any autonomous value because they are used only as means of communication'. Then, he adds the following: 'The contrary takes place in the poetic language: one can affirm that the sounds of the poetic language emerge within the clear field of the consciousness and that the attention is concentrated upon them' (ibid., p. 163). In this context, Jakubinskij (ibid., p. 163) defines the 'clear field of the consciousness' as a 'conscious experience (pereživanie) of the sounds'.

Then, I found the same term in Polivanov's analysis of the phenomenon of alliteration. Polivanov refers to the clear field of the consciousness for explaining the codification of alliteration in the languages with a fixed stress put on the initial syllable. He writes, 'because of the stress put on the initial syllable of the word the first consonant appears on the clearest background of the phonetic influence' ( $v$ naibolee svetlom fone poetičeskogo vlijanija) (quoted in [15], p. 51).

There were some more concepts of this type - and in every instance, there were no comments, definitions or references to these concepts as if they were quite evident for the formalist authors. To solve this problem of opaque concepts, I turned to my colleague and friend David Romand, who is a specialist in the history of psychology, especially of the German psychology of the 19th century. In 2005, he defended his doctoral thesis at the University Paris-7, titled 'La formation du concept d'inconscientcognitif (1815-1970). Contribution à l'histoire de la psychologie et à la théorie des neurosciences cognitives'. Thus, first of all, I asked him the question about 'apperception'. His answer was that I should seek for it in Johannes Herbart's Textbook of Psychology (Lehrbuch zur Psychologie) [16] and then in Wilhelm Wundt's Fundamentals of Psychology [Grundzüge der physiologischen Psychologie) [17].

Then, I asked about 'series', and I was informed that it was the basic concept of Herbart's psychology, and that it signifies a serial functioning of representations within the psyche. Then, there was the question of 'dark and clear fields of the consciousness'; and once more, I learned from him that it was an evident reference to Herbart's dynamic model of consciousness. Herbart distinguishes between two mental zones divided by the threshold of consciousness, which conditions the effect of apperception.

By working with David Romand, I could considerably enlarge my collection of these psychological terms or implicit references in the formalist's texts. For example, one can quote the term predstavlenija (representations), frequently used by Polivanov: while speaking about the elements of language, Polivanov uses the term 
representation; for him, phonemes, syllables, words and phrases are representations experienced by individuals. In the 1974 English translation of Polivanov's selected articles, complied by Alexei Leontiev Jr., the term predstavlenie is translated into the word 'image' [9]. As a result, the psychological significance of this term was lost in translation. For Polivanov, representations of the phonemes are sound representations or elementary phonetic representations [zvuko-predstalenija ili prostye fonetičeskije predstavlenija]. Polivanov distinguishes phonological representations [fonologičeskije predstavlenija] from phonetic representations [fonetičeskije predstavlenija]: the latter are defined as mental activities resulting from the combination of phonological representations [9, pp. 68, 223].

We also found the frequent use of the expression jazykovojemyšlenie [verbal thought or lingual thought] by Polivanov [8, pp. 240, 241, 244, 246, 252]. Later, we found a German equivalent of this term in the contents of Wundt's [30] Sprache, in the first volume of his ethno-psychology, where in das sprachliche Denken is a very commonly used concept.

We also noted the frequent usage of the notions jazykovoj žest (lingual gestures) and zvukovoj žest (sound gesture) by different formalist authors such as Polivanov, Jakubinskij, Osip Brik, Boris Eixenbaum and Tynianov. I will comment later on this important concept within formalism (see supra).

We could also note that some Russian colleagues have started studying the psychological backgrounds of Russian formalism. Thus, according to Irina Sirotkina [18], 19th-century psychology defined automatism in a very positive way, as the most advanced stage of every learning. The formalist critics of automatism and the formalist principle of deautomatisation (ostranenije) break with this tradition [18, pp. 295-317]. Dealing with the formalist discussion about images and the absence of images in poetical thought, llona Svetlikova explains the formalist critics about Aleksandr Potebnja's conception of the poetical word (such as 'thinking with images') through the influence of the psychological school of Würzburg; indeed, the latter affirms the existence of thought without images [19, pp. 244-272]. In 2005, Svetlikova published a monograph Russkij formalism i nemeckaja psixologiteskaja tradicija [Russian formalism and German psychological tradition]. She claims, for instance, that it is impossible to understand Tynianov's book Semantikastixa of 1925 without Herbart's psychology. She makes an interesting analysis of Tynianov's concept tesnota poeticeskogo rjada [the narrowness of a poetical row] and tries to show that this concept is bound to Wundt's idea of apperception: indeed, in his Fundamentals of Psychology, Wundt asserts the 'narrow character of apperception' [20].

These research works together were an important encouragement for our own work, since we got an impression that there was really something to seek in this direction. The collaboration with David Romand yielded a series of publications (see: [21, pp. 223-236]; [22, pp. 3-27]; [23, pp. 521-546]; [24, pp. 10-51]; [25]).

\section{From psychological linguistics to formalism}

But, for us, the basic question was still unresolved. How to explain this massive presence of the psychological terminology in formalist writing?

Because it was quite clear to us that the formalists themselves were not much of readers of psychology. The absence of references and the frequent approximations in their transpositions of the German psychological concepts made me think about other secondary sources.

And, finally, we found the answer. Formalists have taken all these psychological conceptions from the Russian linguistics and poetics of their time. It deals with a very particular type of linguistics called 'psychological linguistics'.

This trend started in Germany around 1850 (Heymann Steinthal [26] [27] [53] [54], Hermann Paul [28] [51] and Georg von der Gabelentz [48]). Very soon, psychological linguistics emerged in Russia under German influence Aleksandr Potebnia's (1835-1891) treaty Mysl' $i$ jazyk [Language and Thought] (1862) was followed by the creation of the so-called Linguistic school of Kharkov. Later, there were two more Russian schools of psychological linguistics: Kazan's school of linguistics, founded by Jan Baudouin de Courtenay (1845-1929), and Filip Fortunatov's (18481914) school of Moscow. This approach was largely diffused by influential scholars, such as Dmitrii OvsianikoKulikovskii (1853-1920, Kharkov School of Linguistics), Jan Baudouin de Courtenay's disciple Mikołaj Kruszewski (Kazan School of Linguistics); Nikolaj Troubetzkoy (1890-1938) and Roman Jakobson (1896-1982). Numerous important Russian linguists of this period were working within the psychological conceptual frame, which was perceived as the only possible scientific orientation. Some formalists, such as Evgenii Polivanov (1891-1938) and Lev Jakubinskij (1892-1945), were direct students of Baudouin de Courtenay. Roman Jakobson was educated in the Department of Linguistics of the University of Moscow, in the atmosphere of Fortunatov's psychological doctrine; this department has preserved until now a real cult of Fortunatov's linguistics. 
Why was the European linguistics of the 1850 s founded on the conceptual apparatus of the scientific psychology of the time?

Since Rasmus Rask (1787-1832) and Franz Bopp (1791-1867), historical and comparative linguistics have accentuated the phonic or morphological (flexional) aspects of language; in other words, the criteria were very substantialist. The notion of 'form', elaborated within the initial frame of comparative linguistics, was conceived in its material aspect: substantial or physical affinities were analysed as the evidence of genealogical relationships. Consequently, emerging psychological linguistics seeks to de-substantiate the notion of 'form', inherited from comparative and historical linguistics. It appears quite logical that the language is conceived, according to Wilhelm von Humboldt's vision, not as ergon - a result or finished product - but as energia, an activity or a pure dynamics. This interpretation of the morphological classification of languages in terms of mental states - as realised later by Heymann Steinthal and Wilhelm Wundt - transformed the idea of 'inner form' of language into a type of psychological classification of linguistic types and constituted a significant stage in the emergence of the psychological trend in linguistics.

There is a basic feature in common between psychology proper and psychological linguistics of the 19th century: both are theories of representation. In this respect, Johann Friedrich Herbart's (1776-1841) contribution is essential. His project on associative psychology has disseminated and also firmly defined the usage of fundamental notions, such as representation (Vorstellung), feeling (Fühlen) and desire (Begehren); serial forms (Reihenformen); the laws of the formation of representational series - converging, amalgamation and inhibition (Hemmung) of representations; the dynamic model of consciousness (the equilibrium and movements of representations); the concept of threshold of consciousness; and, finally, the division into clear and obscure fields of consciousness [16, pp. 54-75].

This was the approach of Heymann Steinthal (1823-1899), the real founder of psychological linguistics and a fervent adherent of Herbart's psychology. Since 1850, Steinthal achieved this de-substantialisation of the morphology of the language in his treaty on the classification of languages. His psychological classification tries to systematise the language as a concept or idea [26, pp. 317-318; ibid., pp. 127-130; 27, pp. 396-431].This classification does not follow the external principle, i.e. the linguistic substance: it retains only the inner principle, the inner form of language, the modality of which is purely energetic, because it deals with the energetic characteristic of speech and thought (cf.: [26, pp. 317-318; ibid., pp. 127-130; 27, pp. 396-431]. In this context, the representational definition of the phrase formulated by Hermann Paul (1846-1921) (Prinzipien der Sprachgeschichte, 1880, §85) is symptomatic: it confirms the representation (Vorstellung) as the basis of new psychological linguistics and attests to the definite assimilation of the mentalist and psychological paradigm by the linguistics of the 1880s: 'The sentence is the linguistic expression or symbol, denoting the combination of several ideas (Vorstellungen) or groups of ideas that has been effected in the mind of the speaker; and it is at the same time the means of reproducing the same combination of the same ideas in the mind of the hearer' [28, p. 111].

The psychologist Wilhelm Wundt (1832-1920) also tried to apprehend the morphological types of languages through the psychological point of view. In particular, he proposed a psychological interpretation of the great morphological types of language established by historical and comparative linguistics. According to Wundt, those three types - isolating, affixing and inflecting - correspond to the three qualitatively different forms of thought. Wundt considers these three forms as three periods of the evolution of the human psyche or essentially different forms of thought. Thus, for Wundt, these morphological stages would reflect the history of consciousness and, in particular, the fact that consciousness tends to be ever more analytical, the activity of consciousness consisting in analysing or decomposing representations; consequently, the development of consciousness would express itself through the way it treats representations (cf:: [29], pp. 364-376; [30], pp. 559-563).

Psychological linguistics borrowed from the psychology of that time the model of representation with two key concepts - 'representation' (Vorstellung) and 'feeling' (Gefühl). These mental entities can be divided into those that can be 'objectified' (Vorstellungen or representations) and those that cannot (Gefühle or feelings), whose function consists of 'colouring' or differentiating between representational contents.

Generally speaking, one finds in the linguistic conceptions of this period the same basic points as within 19thcentury psychology. These points are the following: the use (and probably misuse) of the notion of representation; the analytical approach to the states of mental facts conceived as being potentially objectified; the assimilation of consciousness to the language (and thus, the recourse, firstly, to the concept of 'lingual or verbal thought' [sprachlichesDenken and jazykovojemyšlenie, respectively; and secondly, to the purely psychological mechanisms explaining the functioning of a language, such as association, analogy, apperception, introspection, localisation, 
functional anatomy of the brain, etc.). Following are some essential positions of the German psychological tradition of the 19th century, which express an authentically 'cognitive' research programme:

- Psycho-physical parallelism conveys the idea that the description of the reality can be accomplished on two levels, depending on the point of view from which this reality is apprehended: the external point of view gives access to the 'objective world', and the internal point of view gives access to the 'subjective world';

- Mentalism, the idea according to which mental phenomena exist independently and autonomously and cannot be reduced to the anatomical and physiological substratum;

- Representation, the idea according to which mental phenomena are double entities, tied simultaneously to semantics and experience, possessing the double value of an image and a concept. These entities are further divided into those that can be objectified (representations or Vorstellungen) and those that cannot be objectified (feelings or Gefühle). The latter function consists in colouring and connoting representations.

- Analytism, the idea according to which it is possible to describe and classify mental states, to isolate and objectify them by means of introspection. It also deals with transforming them into qualitatively determined objects belonging to objective knowledge.

- Localisation, the idea according to which it is possible to identify the neuronal substratum that conditions mental phenomena and relates them to the activity of some determined centres of the nervous system.

These commonly shared positions of German psychology of the 19th century plainly justify the term 'cognitive' that we apply to it (concerning the German-Austrian scientific psychology of 19th century as a cognitive paradigm, see for more details: $21 ; 23$, pp. 531-539; 25).

These general lines express the positions of psychological linguistics and the corresponding idea of psychology of this period, particularly in what concerns the place attributed to language. The psychological current within Russian linguistics has popularised the above-mentioned basic notions of 19th-century psychology in the local humanities: representation, feeling, series, the threshold of consciousness, the clear and obscure fields of consciousness, etc. The formal method in literary scholarship largely borrowed the conceptual tools from this branch of linguistics without referring directly to works or conceptions of psychologists; this psycholinguistic filiation became constitutive of the phenomenon of Russian formalism (cf. [31] [56]).

\section{The formal method in Germany and Russia}

To understand the attractiveness of 19th-century psychology for linguistics and humanities of that time, one should take into consideration the following point: the works of psychologists of this period present a systematically and clearly defined research programme. The humanities of this period found, in the psychological stance, a type of common epistemological criterion. The growth of scientific psychology provoked a reconfiguration of the objects and methods of humanities during the last half of the 19th century, in particular within linguistics, anthropology and aesthetics. This psychological tendency affected the whole set of European humanities and was especially strong in Germany and Russia.

Some German aesthetic sources [49] [50] -the importance of which for Russian formalism is well established [55] [59]- participated directly in this psychological paradigm typical for the Western humanities of the second half of the 20th century.

Indeed, all these models belong to the psychology or psycholinguistic aesthetics elaborated under the influence of practicing psychologists, such as Herbart, Lotze, Fechner, Wundt and Lipps. In this respect, the aesthetics of this period shares the destiny of the other humanities of this time such as linguistics and anthropology. That is to say, the European humanities have joined - often too hastily - the conceptual models provided by psychology, this latter being conceived as a real 'epistemological foundation'. In particular, this affinity between the formalist and psychological aesthetics is revealed in the study of Lambert Wiesing [32].

Indeed, the theories of the so-called 'West European Formalism' (to use the notion of Pavel Medvedev from his critics of the formal approach in literary scholarship, 1928: see [33]) are based on the conceptual apparatus of the scientific psychology. Accordingly to Medvedev, 'the European Formalism developed the problem of seeing as the problem of meaningful vision, as the problem of the sensual perception of meaning, or [...] as the problem of the sensual quality burdened with meaning' [33, p. 49]. 
This is the case of Adolf von Hildebrand's idea of the 'constructive aims of art' and the 'architectonic' sense of the work. His conception of the artistic form defines the history of art as the evolution of representations and introduces the notion of artistic form as a problem of perception. Hildebrand's [2] treatise is saturated with psychological terminology, such as 'representation', 'perception', 'sensation', 'function', 'corporeal feeling', etc.

On the epistemological level, the programme of 'the history of art without names' (Kunstgeschichte ohne Namen) and those of 'West European Formalism' have led to the idea of an anti-psychological character of the formalist aesthetics. However, under the cognitive impulse of the German psychology of this period, European formalism formulated an explicitly psychologically based programme of research. Within this programme, the history of art was assimilated into the formative modalities of mental images. Indeed, the anonymous history of artistic styles, the object of this new research programme, is concentrated on the evolution of the modes of perception and on the modification of the relationships between senses. This formalist programme seeks to redefine the sensorial impressions in terms of mental operations and proto-representations. This is the object of Alois Riegl's references to the psychology of perceptions: his psychological stylistics explores the history of art as a tension between tactile sense and visual sense or, in other words, as an evolution of the subjective vision [1]. This is also the problem of the historian of art Wilhelm Wölfflin, who qualifies art as a 'history of expression' and as an 'inner history of the form' [4]. Far from being an exception, Russian formalism reflects - despite a certain chronological delay - this fundamental tendency of European humanities of this time.

For example, the notion of 'sound gesture' unmasks the psychological genealogy of both German and Russian forms of formalism. In fact, this concept seems to be fundamental for formalism both in linguistics and in poetics, but, despite this fact, it has not, in our opinion, been sufficiently commented until now.

We have registered the frequent usage of the notions 'jazykovoj žest' (lingual gestures) and 'zvukovoj žest' (sound gesture) in the texts of different formalist authors, such as Evgenij Polivanov, Lev Jakubinskij, Osip Brik, Boris Eixenbaum and Jurij Tynianov [34, pp. 231-248].

Evgenij Polivanov [9] seems to be the first formalist scholar using this concept in his article 'Po povodu 'zvukovyx žestov' japonskogo jazyka' [About sound gestures in Japanese], published in the first OPOIAZ (Obščestvo Izučenija Poetičeskogo Jazyka, Society for the Study of Poetic Language) collective volume on the theory of poetic language (Sborniki po teorii poetičeskogo jazyka, I, Petrograd, 1916; see also: 'Apropos sound gestures in Japanese', in [9]). In the essay 'About the poetry and trans-rational language' (1916), the formalist theoretician Viktor Šklovskij (1893-1984) explains the phenomenon of 'zaum' (trans-rational poetry) through Wundt's notion of 'sound images' (Lautbilder). For Šklovskij [35], these sound-images are those words the articulation of which corresponds to the facial mimicry that expresses the feelings provoked by these words. According to Šklovskij [35], the existence of these word-sounds confirms the fact that the phonic and the articulating aspects of a word can provoke different emotions. Šklovskij also adds that these sound images express not acoustical but visual representations. He gives several examples of these sound images: karakuli (scrawls), tummeln (to romp about), torkeln (to reel, to stagger) (meanwhile, Šklovskij's quotations from Wundt are borrowed from F. Zelinski, a Russian commentator of Wundt's psychology) [35, p. 48]. One should stress that both Polivanov and Šklovskij refer explicitly to the ethnopsychology of Wundt: while Polivanov mentions the first volume of Wundt's Sprache (the 1900 edition), Šklovskij quotes the above-mentioned Zelinski, and he also seems to know the Russian translation of Wundt's principles of ethnopsychology published in Moscow in 1912. It is a very rare case of an explicit psychological reference within Russian formalism.

For the contemporaries of Russian formalism, the link between the trans-rational language (zaum) of futurism and the expressive gesture in Wundt's sense is very evident. For example, one could quote an important remark of Mixail Baxtin (1895-1975) made in his lectures on the Russian literature of the 1920s. Directly connecting the zaum language to gestures, Baxtin observes that the verbal gesture replaces theme in the experimental poetry of Velimir Hlebnikov (1885-1922), a Russian futurist poet. For Baxtin, Hlebnikov's trans-rational language is dependent on Wundt's psychology. In this context, Baxtin refers to Wundt, for whom the original sound is naturally accompanied by gesture, which, in its turn, results from the imitative capacity of the articulating organs. Much later, the sound becomes self-sufficient, turning into a goal in itself. Initially, the word has no autonomy; it merely accompanies gesticulation, which is not determined by external objects but appears like an inner image of objects. And Baxtin concludes thus: if the gesture is abstract, the word, consequently, is not a label of the object but the expression of the speaker's inner essence [36, p. 368].

Lev Jakubinskij, in his 1923 essay on the dialogical speech defines the gesture as a type of mimicry, a sort of motoric reaction typical for non-linguistic communicative systems; this reaction, according to Jakubinskij, stems from 
the partial reduction of the linguistic message and makes up a part of the 'dialogical speech' (see: Jakubinskij 1986, pp. 122-128, 183-193) [14]. Osip Brik, in his essay Ritm i Sintaksis (1927), relegates any gesticulation (mimicry, motor reactions) to the domain of signal systems that accompany the 'verbal orientation' (rečevaja ustanovka) [37]. Brik compares this secondary signal system to a rhythmic impulse that seeks to increase a material or palpable character of the poetic language (Brik, 1927 in: Stempel, 1972, p. 167) [37]. Juri Tynjanov defines the sound gesture (zvukovoj žest) as a 'deformation', a particular mechanism serving to produce semantic change within a poetic line; for Tynianov, this very phenomenon constitutes the 'semantics of the poetry' [6, p. 140]. Based on this notion of expressive gesture, Boris Eikhenbaum presents his conception of oral narrative (skaz), a particular narrative style imitating an immediate oral telling of a fictive character, where a systematically applied system of deformations leads to a particular semantic effect (e.g. the 'grotesque body' of Gogol's character, Akakij Akakievič, is a pure articulated effect, produced by the articulation of this name) (Ejxenbaum [1918] in: Striedter, 1969, p. 128) [38].

One can define this new gestural object similar to the corporeal body's engagement in speech production. Russian formalism lends this definition of gesture to the German psychology of this period. This interest of the formalists in the corporeal component of lingual and literary production has led to a particular research orientation, which is definable as 'a linguo-somatic orientation' [58].

This idea of the corporeal engagement in language production is particularly characteristic for Wilhelm Wundt's (1832-1920) psychology and the 'sound analysis' (Schallanalyse) of Eduard Sievers (1850-1932), which were largely inspired by the German psychophysics of the second half of the 19th century.

According to Sievers, the emotion - as an original phenomenon - generates a gesture accompanied with a sound (Lautgebärde), which together form a simultaneous phenomenon. Sound realisation through language means an intrinsic semantic charge; it is a physiognomic expression in the same way as a gesture is an expression of the 'soul movement' (quoted in: Frings, 1966 [1933], pp. 47-48 [39]; see also: [52], [40], pp. 145-162).

For W. Wundt (1832-1920), lingual gestures (Sprachgebärde) and the language of gestures (Gebärdensprache), as well as 'sound metaphors', are the most explicit manifestations of what he calls 'expressive movements' (Ausdrucksbewegungen). This type of movement is understood as the instinctive movements that accompany the affects. They are physiologically determined phenomena, such as different changes in physical states such as acceleration and slowing down of the heart rhythm, acceleration and slowing down of respiration, instinctive contraction of the facial muscles, etc. These 'expressive movements' of Wundt illustrate the principle of psychophysical parallelism elaborated by German psychology since the 1860s: according to this principle, every change in the psychical state is accompanied by an equivalent change of the physical state, every dimension being governed by some particular non-correlated laws. The 'expressive movements' appear as real distinctive features within every affective communication. For Wundt, a phonic language is but part of this complex of 'expressive movements' naturally characteristic of a human organism (Wundt, 1900, B. 1, pp. 73-79, 151-154) [30].

This concept of 'expressive movements' has profoundly influenced the German aesthetics of the last half of the 19th century. In particular, this is the case of Konrad Fiedler's (1841-1895) 'sensorial aesthetics' developed in his treatise On the Origin of the Artistic Creativity (1887). Fiedler defines art and the artistic production as a set of 'expressive movements' derived from the productivity of the human psyche: they contribute to the formation of the works of art. These 'expressive movements' extract forms from the consciousness (which is amorphous by its nature). For Fiedler, 'expressive' means 'morphogenetic': it deals with the generation of forms whose content does not precede this process. The essence of 'expressive movements' is not the fact that some mental content finds external expression through the movement of physical organs. Fiedler sees these 'expressive movements' as a particular stage in the development of the psychophysical process. The mental process, as an immediately conscious object, receives in 'expressive movements' a development that would be impossible without these 'movements': one finds here the same phenomenon as in every corporeal process, which begins with nerve excitement and reaches, in an immediate external movement, the phase of development that it would not reach in any other way [3, pp. 193-194].

Thus, Fiedler eliminates all separation between body and psyche, external and internal: in terms of language, this means elimination of any distinction between the signifier and the signified. Fiedler envisions a kind of 'embodiment of the visual' taking place in the realm of pictures. Fiedler's conception accentuates the autonomy of the act of seeing and its processual character. Besides, it seeks to free the eye both from a possibility of 'innocent seeing' and from the everyday conventions of seeing practice. The improving or perfecting of sight is achieved through 'expressive movements' or the language of expressive gestures. The latter conditions the autonomy of the act of seeing, as they allow the seeing process to keep its content immanent. Far from imitating or doubling reality, the 
act of seeing is conceived as a reality in itself. The development of seeing in Fiedler's sense is connected to the frontier that marks the end of the eye's activity. The intervention of the hand enlarges the perceptive power of the eye. Thus, it frees the act of seeing from all possible contexts and it brings seeing to the state of 'pure visibility'. The visual force of perception is accomplished and fully completed in painting through the 'Logos of the eye' (see: [41, p. 36]). Seeing shares this point with language understood as a self-producing system: both constitute a particular type of 'expressive movements'. This basic idea of 'expressive movements' of perception is the foundation of what is often called 'the doctrine of Fiedler-Hildebrand' (Fiedler-Hildebrand'sche Lehre) (ibid., pp. 28-29).

Fiedler's ideas transfer Humboldt's notion of the inner form of language into the sphere of the visual, seeking to present art as language. It also testifies to the extreme psychologisation of European humanities (and aesthetics in particular) at the turn of the 20th century.

The concept of 'expressive movements' is omnipresent in the context of German humanities. One finds it even in the field of theosophy: thus, Rudolf Steiner, the founder of anthroposophy, in 1907, exposed his programme of the new science called 'eurythmy' and defined as 'a completely new art' seeking to express sound and verbal qualities through precise movements. This new art is introduced like a visible song and a visible language. It is connected to the physiology of movements, which founds the speech and the song; it expresses the idea according to which the whole organism - through its resonance - participates in the accentuated pronouncement of the sounds of language $[42,43]$.

In the third volume of his Philosophy of Symbolic Forms, Ernst Cassirer (1874-1945) summarises the research on 'expressive movements' in the following words: 'Modern psychology was right to classify the problem of language among the problems of the general psychology of 'expressive movements' [44, p. 129]. Cassirer considers the movement and the feeling of movement as fully autonomous elements, fundamental for the construction of the consciousness. For Cassirer, the expressive movement is an immediate unity of the inner and the external; the spiritual and the corporeal. In his view, the expressive movement is not an arbitrary addition of a mimetic sign to some emotive state designated through it. These two elements - emotion and its exteriorisation, inner tension and its liberation - are given in one and only simultaneous act [44, p. 129].

Expressive movements appear on the motoric level of motricity, beyond the mechanical reflexes, being, according to Cassirer, 'a higher spiritual spontaneity'. The latter constitutes the first threshold of spiritual development because this phenomenon is simultaneously situated in the immediate character of the sensible life and beyond it [ibid., p. 130].

This perfect fusion of the spiritual content and its sensible expression observed in the 'expressive movements' allows the perception of the psychical mechanism of the origins of language. Indeed, according to Cassirer, the birth of language is characterised through this reciprocal inter-penetration of content and expression. The birth of language is marked by this remarkable indifference of the inner and exterior spheres, and this indifference generates the signification and the language as 'totality' [lbid., p. 128].

Thus, Russian formalism - as well as its Occidental counterpart - showed itself very receptive towards the new conception of psychic life elaborated by the German psychologists during the 19th century [57], towards the cognitive tradition inherited by modern neuroscience. The formalist research programme was presented by the formalists themselves as an 'anti-psychological' reaction against some dominating research tendencies; later, it was also interpreted this way by different commentators and historians of formalism. However, attentive reading of formalist texts beyond purely declarative programmes reveals that they are saturated with psychological conceptions and terminology. This psychological background constitutes a rather heterogeneous constellation composed by means of psychological aesthetics and psychological linguistics of the second half of the 19th century.

\section{The cognitive dimension of Russian formalism}

Independently of its intrinsic theoretical values, the formalist way of thinking about language and literature is based on the implicit dominance of psychology and it takes its sense only in terms of the German cognitive tradition, appropriated by the Geisteswissenschaften of this time. In this respect, Russian formalism participates in the large movement of psychologisation of the humanities. This process has begun from the 1850 s and has continued during the 20th century, much longer than one usually thinks. The representative case of Russian formalism invites a rethinking of the genealogy of European structuralism in general.

This accumulation of conceptual tools borrowed from the German psychological tradition also reveals a cognitive charge of the formalist theories. The latter constitute a conceptual link between the properly psychological past of 
the European Geisteswissenschaften and the cognitivist future of the actual research programmes (see on the modality of this transfer: Romand \& Tchougounnikov (dir.), 2009) [22]. Beyond the borrowing of conceptual tools from the psychological trend, the formal method has found in it its inspiration for producing new models of analysis. This intrinsically cognitivist dimension of the formalist programme explains its late success during the 1950s-1960s, the period often and abusively called the period of the cognitivist revolution. In reality, it deals with a re-emergence of the research programme of the cognitivist sciences, rather exhaustively formulated by the German psychological tradition. This cognitivist genealogy of Russian formalism shows the perennial character of the cognitivist thought within some fields of humanities. This type of thought has subsisted even during the period when the cognitivist research programme was eclipsed and the humanities were seeking to reformulate their programme on a clearly 'anti-psychological' basis during the behaviourist age in psychology (see: [22].).

We can now formulate some more general hypotheses concerning the epistemological method of Russian formalism and its place within the general epistemology of the humanities:

1. Russian formalism is dependent on two great lines within the 19th-century psychological tradition:

a) The theory of representation, understood as a unity characterised through double determination - qualitative and quantitative; b) localisation of lingual and semiotic mechanisms with respect to some basic neuroanatomic centres. This trend continued within the formalist circle and has survived in a particular branch of structuralism, represented by Jakobson's linguistics and Russian Moscow-Tartu semiotics.

2. The formalism programme takes over some essential constituents of Wundt's physiological psychology, namely the idea of the affective and expressive nature of language. Certain formalist concepts (such as skaz or oral narration, poetic language as well as ostranenie or deformation) allow to comprehend the expressive movements in language. The quest of this expressive or mimetic dominance through the language and the literature allows the attachment of formalism to the psychological trend in linguistics as well as to the romantic theory of expression (see on this point: [45]).

3. The formalist paradigm was consolidated within the science of language as a refusal of the passive or unconscious association model conceived by Herbart's psychology for the sake of Wundt's active or voluntarist apperception.

4. The formal method was inspired by the anatomo-physiological approach of German psychology: this inspiration makes it participate in the programme of 'naturalisation' of the language, the programme implying the mechanisms of language to different problems of biological type (see: [46]). This was the reason why the Russian theorists as well as the formalists and the semioticians of the Moscow Tartu School - were led to define the organic and physiological conditions of the semiological entities constitutive of the consciousness. Besides, this 'naturalistic' programme seems to explain the functionalist dominance within this type of structuralism: it gives a missing link for understanding functionalist turns, such as the transition between the last formalism and the linguistic circle of Prague, continuing in the Russian-Soviet structuralism of the 1960s and 1980s. Thus, Jakobson's idea of the localisation of the paradigmatic and syntagmatic axes as well as the idea of the functional dichotomy of the brain were elaborated by the semiotics of Moscow and Tartu in terms of the functional asymmetry of the brain (which was developed in a collection of articles dealing with brain asymmetry, such as a semiotic mechanism) (see, e.g.: [47]).

The consequences of this process of psychologisation of the humanities dated from the 1850 s were decisive for the later history and epistemology of Russian linguistics and poetics. In particular, they have manifested themselves in the theorisation of language elaborated within psychology through action: those of Vygotsky and Leontiev; the importance of the early psycholinguistic tradition for the Moscow-Tartu semiotics has been already mentioned. In our opinion, the Russian semiotic tradition is, to some extent, a completion of the psychological age of linguistics.

\section{Conclusion}

Following the research programme of psychology of the 19th century, psychological linguistics, itself the product of the psychologisation of the humanities (Geisteswissenschfaten), has powerfully contributed to the creation of a modern epistemological frame. The conceptual heritage of the psychological linguistics of the 19th century is inevitable epistemological data, the study of which is extremely useful for the general history of cognitivism. The case of psychological linguistics illustrates the basic tendency that operated during the second half of the 19th century, the tendency that has finally transformed the situation within the European humanities. This tendency can 
be defined as a general movement of the psychologisation of knowing by means of diffusion and assimilation of German cognitive models. Psychological linguistics has applied the German cognitive model to the language and has defined the language as its privileged object: it has contributed to the re-emergence of the research programme, initially elaborated within the German-Austrian psychological tradition. Thus, the experience of psychological linguistics invites us to rethink the history and the genealogy of the cognitivist thought.

\section{References}

[1] Riegl A., [1901] 1973. L'Industrie d'art romaine tardive, trad. all. Die spätrömische Kunstindustrie nach den Funden in Österreich-Ungarn, Darmstadt: Wissenschaftliche Buchgesellschaft.

[2] von Hildebrand, A., [1909] 1969. Das Problem der Form. In von Hildebrand, A., (Ed.), Gesammelte Schriften zur Kunst. Köln: Westdeutscher Verlag.

[3] Fiedler, K., [1887] 1971. Schriften zur Kunst, B. 1. München: W. Fink Verlag.

[4] Wölfflin, H., [1915] 1983. Kunstgeschichtliche Grundbegriffe. Das Problem der Stilentwicklung in der neuren Kunst. Dresden: VEB Verlag der Kunst.

[5] Worringer, W., [1908] 1978. Abstraction et Einfülhung. Paris: Klincksieck.

[6] Walzel, Oskar, Gehalt und Gestalt im Kunstwerk des Dichters, Berlin, Akademische Verlagsgesellschaft Athenaion, 1923.

[7] Tynianov, J., [1924] 1977. Le vers lui-même. Les problèmes du vers. Paris: Union générale d'éditions.

[8] Polivanov, E., 1931. Za marksistskoje jazykoznanie [Towards the Marxist linguistics]. Moscow: Federacija.

[9] Polivanov, E., 1968. Stat'i po obsščemu jazykoznaniju [Essays on general linguistics]. Moscow: Nauka.

[10] Polivanov, E., 1974. Selected works: Articles on general linguistics. Compiled by A.A. Leontev. The Hague, Paris: Mouton.

[11] Vološinov, V., [1930] 2010. Marxisme et philosophie $d u$ langage. Les problèmes fondamentaux de la méthode sociologique dans la science du langage, trad. par P. Sériot et I. Tylkowski-Ageeva. Limoges: Lambert-Lucas.

[12] Tynianov, J., [1927] 1972. O literaturnojevol'ucii. In Stempel, W.-D. (org.), Texte der russischen Formalisten, Band 2, München: Wilhelm Fink Verlag.

[13] Tynianov, J., Jakobson, R., [1928] 1965. Les problèmes des études littéraires et linguistiques. In Todorov, T., (Éd.), Théorie de la littérature. Textes des formalistes russes, Paris: Seuil.

[14] Jakubinskij, L., 1986. Jazyk i ego funkcionirovanije. Izbrannye raboty [Language and ist functionning]. Moscow: Nauka.
[15] Larcev, V., 1988. Evgenij Dmitrievič Polivanov. Stranicy žizni i dejatel'nosti [Evgenij Polivanov. His life and his work]. Moscow: Nauka.

[16] Herbart, J.F., [1816] 1834. Lehrbuch zur Psychologie. Königsberg, (1965. Nachdruck der erste Ausgabe. Amsterdam: E. J. Bonset).

[17] Wundt, W., [1874] (1908, 1910, 1911). Grundzüge der physiologischen Psychologie, 3 vol., Leipzig: Engelmann.

[18] Sirotkina, I., 2004. Teorija avtomatizma do formalistov [The theory of automatization before formalists]. In : Zenkin S. (ed.), Russkaja Teorija 1920-1930, gody. Materialy 10 Lotmanovskix čtenij. Moscow: RGGU, pp. 295-317.

[19] Svetlikova, I., 2004. Obrazy : odna polemičeskaja koncepcija formal'noj školy [Images: about one polemical conception of the formal school]. In Zenkin S. (ed.), RusskajaTeorija 1920-1930, gody. Materialy 10 Lotmanovskix čtenij 2004, pp. 295296, Moscou: RGGU, pp. 244-272.

[20] Svetlikova, I., 2005. Istoki russkogo formalizma. Tradicija psixologizma $i$ formalnaja škola [Some sources of the Russian formalism: The tradition of psychologism and the formal school]. Moscow: Novojeliteraturnoeobozrenije.

[21] Romand, D., Tchougounnikov, S., 2008. Quelques sources psychologiques allemandes du formalisme russe: le cas des théories de la conscience. In Langage et pensée: Union soviétique années 1920-1930. Cahiers de I'ILSL, No 24. Lausanne: Université de Lausanne, pp. 223-236.

[22] Romand, D., Tchougounnikov, S., 2009. Aux origines allemandes du cognitivisme, introduction. In Romand, D., Tchougounnikov, S. (dir.). Psychologie allemande et sciences humaines en Russie: anatomie d'un transfert culturel (18601930). Revue d'Histoire des Sciences Humaines 21, pp. 3-27.

[23] Romand, D., Tchougounnikov, S., 2010. Le formalisme russe, une séduction cognitiviste. In Berelowitch W. \& Espagne M. (org.), Cahiers du Monde russe, $N^{\circ}$ 51/4, Sciences humaines et sociales en Russie à l'Âge d'argent: quelques figures de transferts, pp. 521-546. 
[24] Romand, D., Tchougounnikov, S., 2012. Psychologie et sciences du langage entre Allemagne et Russie (1850-1920): pour une histoire de la psychologisation des sciences humaines européennes. In Burov, A. (ed.), Rusistika za 200 let : včera, segodnja, zavtra [200 years of Russian studies: yesterday, today, tomorrow]. Piatigorsk: Université d'Etat de Piatigorsk, pp. 10-51.

[25] Romand, D., Tchougounnikov, S., 2013. Polivanov, psycholinguiste. Psychologie et formalisme en Russie dans les années 1910-1930. In Archaimbault, S., Tchougounnikov, S. (Éd.), Evgenij Polivanov (1891-1938). Penser le langage aux temps de Staline. Paris: Institut d'études slaves, pp. 83-121.

[26] Steinthal, H., 1860. Charakteristik der hautsächlichsten Typen des Sprachbaues (2 Auflage). Berlin: Ferd. Dümmlers Verlagsbuchhandlung.

[27] Steinthal, H., 1881. Abriss der Sprachwissenschaft. Einleitung in die Psychologie und Sprachwissenschaft. Erster Teil. Die Sprache im Allgemeinen (Zweite Auflage). Berlin: Ferd. Dümmlers Verlagsbuchhandlung, Harrwitz und Gossmann.

[28] Paul, H., 1891. Principles of the history of language. London and New York: Longmans, Green and Co.

[29] Wundt, W., 1863. Vorlesungen über die Menschenund Thierseele. B. 2, Leipzig: Leopold Voss.

[30] Wundt, W., 1900. Völkerpsychologie. Die Sprache. B. 1, Leipzig: Engelmann.

[31] Tchougounnikov, S., 2012. Du « psychologisme " $a u$ " cognitivisme ". La " linguistique psychologique » entre Allemagne et Russie (18501930). L'émergence d'une psycholinguistique européenne. Mémoire d'Habilitation à diriger des recherches. Paris: Université Paris-7.

[32] Wiesing, L., [1997] 2014. La visibilié de l'image. Histoire et perspectives de l'esthétique formelle, traduction par Carole Maigné. Paris: Vrin.

[33] Medvedev, P. [Baktin, M.], [1928] 1991. The formal Method in Literary scholarship. A critical introduction to Sociological Poetics. Baltimore \& London: The Johns Hopkins University Press.

[34] Tchougounnikov, S., 2009. La psychologie allemande dans la généalogie du formalisme russe. In Trautmann-Waller, C., Magné, C., (Éds.), Formalismes esthétiques ethéritageherbartien. Vienne, Prague, Hildesheim, Zürich, New York: Georg Olms Verlag, pp. 231-248.

[35] Šklovskij, V., 1990. Gamburgskij sčët. Moscow: Sovetskij pisatel'.
[36] Baxtin, M. [Bakhtine, M.], 2000. Polnoe sobranie sočinenij. Vol. 2. Moskva: Russkijeslovari.

[37] Brik, O., [1927] 1972. Ritm i sintaksis. In WolfDieter (hrsg.), Stempel. Texte der russischen Formalismus, B. 2. München: Wilhelm Fink Verlag.

[38] Ejxenbaum, B., [1919] 1969. Kaksdelanašinel“ Gogol'a. In Striedter, J. (org.), Texte der russischen Formalisten, Band 1. München: W. Fink Verlag.

[39] Frings, Th., [1933] 1966. Eduard Sievers. In Sebeok, Th. (Ed.), Portraits of linguists for the history of eastern Linguistics, 1746-1963, Vol. II. Bloomington and London: Indiana University Press.

[40] Tchougounnikov, S., 2007. Eduard Sievers et la phonétique allemande du début du XXème siècle. Les sources allemandes des théorisations russes de la charpente sonore du langage. In Histoire. Epistémologie. Langage, t. XXIX, Fascicule 2, Paris, Université de Paris-7, pp. 145-162.

[41] Boehm, G., 1997. Die Logik des Auges. Konrad Fiedler nach einhundert Jahren. In Majetschak, S (hrsg.), Augen und Hand. Konrad Fiedlers Kunsttheorie im Kontext. München: W. Fink Verlag, pp. 27-40.

[42] Steiner, R., 1927, Eurythmie als sichtbare Sprache. Dornach: Philosophisch- Anthroposophischer Verlag am Goetheanum.

[43] Steiner, R., 1945. Pädagogischer Kurs. Bern: Troxler-verlag.

[44] Cassirer, E., [1923] 1972. La philosophie des formes symboliques, Tome 3. La phénoménologie de la connaissance. Paris: Minuit.

[45] Tchougounnikov, S., 2005. Entre "organicisme " et "post-structuralisme »: deux âges du discours russe - soviétique sur le langage et la littérature (1914-1993). Magnitogorsk: Université d'Etat de Magnitogorsk.

[46] Romand, D., 2010. 'Das Köper-Seele Problem” La question du rapport du psychique au physique dans la psychologie allemande du 19e siècle. In Friedrich, J., Gillot, P. (dir.), L'intériorité mentale et le lieu de la pensée. La Revue de Synthèse 131(1), Paris : Springer Verlag, pp. 35-52.

[47] Minc, Z. (dir.), 1983. Trudy poznakovym sistemam [Studies on the secondary signifying systems], N¹6. Tartu: Tartuskij Universitet.

[48] Gabelentz, G., [1891, 1901] 1972. Die Sprachwissenschaft, ihre Aufgaben, Methoden und bisherigen Ergebnisse. Tübingen: Universität von Tübingen.

[49] Maigné, C., Trautmann-Waller, C. (dir.), 2009. Formalismesesthétiques ethéritageherbartien. 
Vienne, Prague, Moscou, Hildesheim, Zürich, New York: OlmsVerlag.

[50] Maigné, C. (Éd.), 2012. Formalisme esthétique. Prague et Vienne au XIXe siècle. Paris: Vrin.

[51] Paul, H., [1920] 1970. Prinzipien der Sprachgeschichte. Tübingen: Max Niemeyer Verlag.

[52] Sievers, E., 1924. Ziele und Wege der Schallanalyse. Heidelberg: Carl Winter's Universitätsbuchhandlung.

[53] Steinthal, H., 1855. Grammatik, Logik und Psychologie. Ihr Prinzipien und ihr Verhältnis zu einander. Berlin: Fer.Dümmler's Verlagsbuchhandlung.

[54] Steinthal, H. 1858. Der Ursprung der Sprache. Im Zusammenhange mit den letzten Fragen alles Wissens. Eine Darstellung, Kritik und Fortentwicklung der vorzüglichsten Ansichten. Berlin: Ferd. Dümmlers Verlagsbuchhandlung.

[55] Tchougounnikov, S. 2009. Quelques éléments ethnopsychologiques et psychophysiques dans les sciences du langage russes de l'entre-deuxguerres. In Romand, D., Tchougounnikov, S., (dir.). Psychologie allemande et sciences humaines en Russie. Anatomie d'un transfert culturel (18601930). RHSH (Revue d'histoire des sciences humaines) $\mathrm{N}^{\circ} 21$. Paris: Sciences humaines Editions, pp. 83-102.

[56] Tchougounnikov, S., 2016. Le sentiment comme facteur sémantique: la sémantique représentationnelle entre la linguistique psychologique et le formalisme. In Pamies, A., Monneret, P., Mejri, S. (Eds.), Langage Design. Special issue: Analogie, figement et polysémie, available at: <http://elies.rediris.es/Language_ Design/LD-SI-2016/indice_SI2016.html>.

[57] Tchougounnikov, S., 2016. L'espace comme procédé: Formalisme russe vs formalisme germanique. In Simonato, E., Moret, S., Cinquante nuances du temps et de l'espace dans les théories linguistiques, Cahiers de l'ILSL, N49. Lausanne: Université de Lausanne, pp. 27-51.

[58] Tchougounnikov, S., 2016. Speech technology as an experimental science: Towards the comparative dynamics of Sprechkunde in Germany and Russia in the late nineteenth to early twentieth century. In Postoutenko, K., Jacq, J., Tchougounnikov, S., Zakharin, D. (Éd.), Secondary Orality in Modern Russian Culture: Language, Cinema and Politics 8 (2), Special Issue of the Russian Journal of Communication (RJC), Routledge: Taylor \& Francis Group, pp. 153-167.

[59] Tchougounnikov, S. 2017. Prolegomeny k sravnitel'nomu analizu russkogo i nemeckojazycnogo formalizmov. In Levcenko, J., Pilschikov, I. (Eds.), Russkij formalism isovremennojegumanitarnoeznanie. Moskva: Novoje literaturnoje obozrenije, pp. 103-114. 